\title{
The Menace of Secret Cults in Higher Educational Institutions in Nigeria
}

\author{
Emperor Kpangban*, Sylvester E. Umudhe and O. P.Ajaja** \\ Department of Science Education, Delta State University, Abraka, Nigeria \\ E-mail:*<emkpangban@yahoo.com>,**<osawaruajaja@yahoo.com
}

KEYWORDS Secrecy; rape; maiming; killing; drugs; terrorist

\begin{abstract}
This study was undertaken to establish the reasons why students in higher educational institutions in Delta State of Nigeria join secret cults on the campuses, the effects of the incidence, and the strategies to employ to eradicate it from the institutions. It was a descriptive survey in design, and using a systematic, proportionate random sample of 665 students, 220 lecturers and 115 school administrators in the state-owned University, three Colleges of Education and three Polytechnics, who duly completed a closed-ended and open-ended 31-item questionnaire, the study confirmed the supposition that students join secret cults in the institutions to terrorize lecturers to pass their courses at all cost, and to provide security services to new initiates and shield them from oppressive students and the perceived hostility of wicked lecturers. A number of effects of the secret cults in the institutions were also established, some of these being cultism leading to certificates not being backed up with true academic struggle, and this leading to reduction in manpower quality; by design, cultists seriously abusing hard drugs like cocaine and alcohol, and in that state of mind, committing heinous crimes; identified and expelled cultists possibly becoming school drop-outs, robbers, prostitutes, drug-peddlers and maladjusted people in life; and cultists spearheading riots at the slightest opportunity and in the process looting and causing damage to school property. It was then concluded that the solution to the menace of secret cults in the institutions rests with evolving a broadbased approach which should involve all stakeholders-students, lecturers, institutions' authorities and government.
\end{abstract}

\section{INTRODUCTION}

In the beginnings of formal education in Nigeria, it was a thing of joy and honour (indeed an achievement which called for celebration) for any young person to be offered admission into a degree programme in any of the few universities in the country then. It was an occasion which everybody, including their parents, looked forward to, especially the accompanying matriculation exercises which the new intake celebrated with pomp and pageantry, to the envy of their less fortunate relations and friends. That was in the days of the "Ivory Tower" concept of the universities, when universities were repositories for high ideals and enviable academic traditions. But today things are different, as it is common knowledge that in Nigeria today studying at University or any other higher educational institution for that matter is nightmarish and a necessary evil. Musa (1998) had earlier on documented this, but we dare say that the situation has been growing worse by

Address for correspondence:

Dr. Emperor Kpangban

Department of Science Education, Delta State University

Abraka-Nigeria, GSM No: 08036784815

E-mail: emkpangban@yahoo.com the day since then. In the place of the erstwhile high ideals and enviable academic traditions are a barrage of evils that are hydra-headed. For example, when some parents are not hiring some University undergraduates to write the University Matriculation Examination (UME) for their children, they are paying money to some examination official to manipulate the scores in the computer. On the campuses, when some students are not cheating in the examination hall, they are busy extorting money from some innocent new intake, called JAMBITES. Furthermore, when some male students are not raping innocent girls, they are brazenly gunning down opponents in the very frequent inter-cult fracas. It is such a tale of woes for many a student and their parents that it is considered expedient to tell the world that the Nigeria higher educational system has come under siege from the nefarious activities of secret cults. Indeed, the menace of secret cults has reached such alarming proportions that university administrators and parents are having sleepless nights over the maintenance of law and order on the campuses; and everybody, including government and the national economy, is counting their losses.

But what is a secret a cult? What is its conceptualization on the Nigeria higher education 
scene? What are the nature and scope of its operations in the Nigerian situation? How widespread and devastating are its operations? What is the way forward in the Nigerian situation that can enable other countries to take steps to avoid her pitfalls and hence not experience the negative influence of secret cults in such countries?

A secret cult within an educational institution may be seen as a group of students bound together with an oath of secrecy to invite strange, supernatural and mysterious powers to guide, guard and protect them (Igborgbor, 2006). Indeed, as expatiated by Egbule (2006), for any cult to be secret, members will have to deny on oath its existence. Secret cults in Nigeria's higher educational institutions, like Western education, were reportedly imported from Europe and the Americas by Nigerians who had gone there for the golden fleece. As revealed by Musa (1998) and Egbule (2006), in the United States of America, for example, cults have always existed both in the larger society and in the institutions of higher learning. There, they are generally referred to as "Greek" and they take on Latin names among youths - like Sigma Delta, Chi, Phi Beta Kappa, Delta Kappa, Opsilon and so on. There, too, they exist in colleges and universities as harmless sonorities and fraternities.

Secret cults in tertiary institutions in Nigeria also had similar noble beginnings. As revealed by Onodarho (1999), the first secret cult in a higher educational institution in Nigeria was founded by a group of seven students led by the now Nobel Laureate, Professor Wole Soyinka, at the University of Ibadan in 1952. Known as the Pyrate Confraternity (or sea dogs), the group existed to fight colonialism, ensure the dignity of man and rid the Nigerian society of elitism, tribalism and so on. As "pirates", members sailed to high seas to "prosecute" evildoers, injustice, corruption and oppression which characterized the few universities in the country at that time. As part of their activities, too, they donated blood to hospitals to save lives, presented gifts to orphanages and generally assisted the poor. Other secret cults then included the Dragons and Buccaneers. Thus, the intention of the secret cults was not to harm, maim, kill and destroy, as their cohesiveness and absolute allegiance to rules made the secret cults become elite clubs meant only for the cleanest, brightest and politically conscious. Their existence on campuses was well known by students and was not associated with weird, harmful and spiteful characters of the latter-day confraternities (Ogharaerumi, 2006).

The various secret cults on Campuses in Nigeria operate under different groups for different purposes. For example, the Black Axe, the Vikings, the Pyrates and the Buccaneers are the most violent and they carry out terrorist activities. Another group made up of the Mafians and the KKK perpetrate drug peddling on campuses. Then female cult groups like the Black Brassieres or Black Bowls and the Amazons assist the male groups, serving as spies and meeting the sexual needs of members of the male groups. Then some other groups act as barons or god-fathers, providing security services to new initiates, and generally shielding them from oppressive students and the perceived aggression and hostility of wicked lecturers. Thus, what can be gleaned from the separate accounts by Musa (1998) and Egbule (2006) is that in Nigeria, students in higher educational institutions join secret cults on the campuses because of the following reasons, among others:

(1) to carry out terrorist activities;

(2) to perpetrate drug peddling on campuses;

(3) to act as barons or god-fathers, providing security services to new initiates, and generally shielding them from oppressive students and the perceived aggression and hostility of wicked lecturers; and

(4) if a female cult group, to assist the male cult groups, serving as spies and meeting the sexual needs of members of the male groups. Taken together, the negative effects of all these secret cults are monumental. The extent of damage done to the psyche of the higher education student, his parents, the undergraduate population and national productivity is thus presented in the next section of this paper, to enable the world appreciate the trauma that the Nigerian nation has been experiencing on account of the presence of secret cults in her higher educational institutions.

On effects of cultism on the higher educational system in Nigeria, Ogbu (2001) has asserted that cultism is an evil association which puts bondage on its members and denies them of personal liberty. The share imagination of cultism is evil.

Cultists kill and maim. They have no lofty objective. The only thing they know is violence 
(Onodarho, 1999; Egbule, 2006). In the event of fighting rival groups, they kill one another. Parents, relations and friends lose loved ones. Parents who had spent all their resources to bring up their children and wards for dependence at old age live the remaining part of their lives unhappy, frustrated and full of regrets.

Cultists when identified are rusticated for years and in most cases are expelled from their institutions. All school authorities and the federal government outlaw cultism. The expelled cultists end up as drop-outs from school. Their lives thereafter are ruled by unfulfilled dreams. Some of the drop-outs become armed robbers, prostitutes and drug-peddlers. The society suffers in terms of fall in morals.

Identified cultists lose credibility in the eyes of the entire school community. Many reasonable people may not want to identify with them. They are often isolated and never given any position which demands a lot of trust and dignity. This stigma remains with them for a very long time, even till death. Cultists apprehended by security operatives are treated as criminals, like armed robbers. They are killed like animals and their corpses displayed with no respect which a normal human being would have deserved.

Cultists lose their individuality and liberty to live normal life (Igborgbor, 2006; Egbule, 2006). They live according to the dictates of their associations. Some become murderers because of the directives of their cults. Some become armed robbers, thieves and liars in their effort to raise money to meet their obligations to their cults. The female cultists are reduced to "call girls" to bring money to their cult boy-friends. No member ordered to carry out any activity refuses lest he or she be killed.

Cultism encourages the use of hard drugs (Onodarho, 1999; Egbule, 2006). Members seriously abuse drugs. Indian hemp, cocaine, heroin, alcohol and so on are freely shared and used in their meetings. It is under the influence of these drugs that they seem to do all the killings without any human feeling and remorse. In 2004, a female student in Delta State University, Abraka, Nigeria, and a girl-friend of a cultist in University of Benin, Nigeria, was killed and hewed into pieces on the instruction of her boy-friend. The offence she committed was that she said she wanted to pull out of the relationship to enable her marry. The killing and hewing into pieces would not have come from a sane person except under the influence of drugs.
Cultism makes cult students live in fear and are ruled by fear. The fear is as a result of possible attack by rival groups. In their halls of residence they are afraid, in lecture rooms, library and even while walking along the streets they are afraid. All these lead to loss of concentration in their studies. Some on their own stop going to lectures because of threat from rival groups. Some parents have to withdraw their wards from school because of threat from cultists. For some, that may be the end of their schooling.

Cultists disrupt normal school activities. In the event of fighting among rival groups or adverse security reports of possible out-break of violence as a result of cult activities, the school authorities close down such institutions. The reopening may last for a long time depending on the severity of their activities. In such circumstances, innocent and poor students suffer in terms of staying longer than necessary in a programme and in terms of loss of personal effects.

Many cultists end up as examination cheats and perform very poorly in their respective courses. The reason is not far-fetched. They are not always in class and will never know what the class is doing and where they are. Students caught for examination malpractice offences are rusticated in most universities in Nigeria. This is why most cultists spend as long as eight years for a four-year degree programme (Otoibhi, 1999; Igborgbor, 2006).

After so many years of killing and all forms of evil activities, frustration and regrets set in among student cultists. The spirits of innocent students they have killed seem to hunt them. Some live a life of regrets all through while some summon enough courage to confess and denounce their membership.

Rape and all forms of sexual abuses are common practices among cult members. They expose themselves to HIV infection and also spread HIV to innocent persons. This is because cultists frequently organize sex parties.

Cultists disrupt examinations to have their way. A case in point is the event which took place at Enugu State University of Science and Technology, Nigeria. Two young men walked into an examination venue and fired gun shots into the air to scare people away. In the confusion which ensued, they got at their target and murdered him in cold blood (Igborgbor, 2006). The authors also witnessed a similar incident at 
Delta State University, Abraka, Nigeria, in 2005. A mercenary who was hired from University of Benin, Nigeria, to write a paper for the girl-friend fired gun shots in the examination hall to escape arrest. This led to confusion everywhere.

Cultists spearhead riots at the slightest complaint. In the process of rioting, they loot school property, burn down buildings, humiliate school authorities, create uncertainty and hardship in the school community and breakdown of law and order. A former ViceChancellor of Delta State University, Abraka, Nigeria, during a riot was carried in a car boot to Edo State University, Ekpoma, Nigeria, blindfolded. In all, cultism and cult-related activities in Nigerian institutions of higher learning result in producing graduates who know next to nothing in their various fields of study.

On strategies for eradicating the incidence of cultism from the Nigeria higher educational system, Smah (2000) and Awe (2001) posit that students, the institutions' authorities, parents and even the government have all been implicated for the existence of secret cults in Nigerian tertiary institutions. Thus, any strategies for eradicating the menace must of necessity involve these identified stakeholders.

In a study conducted by Adeola (1997), it was shown that many respondents $(41.2 \%)$ indicated that students should be considered the most ideal to have the mandate to intervene in the control of campus cultism. Students who are cultists live among those who are non-cultists either in the hostels or off-campus where the former plan and execute their nefarious activities. It is, therefore, easier for the non-cultist students than any other person or group of persons to identify and locate their cultist counterparts. Non-cultists among the students will thus be very helpful in the cultism eradication process by not only exposing those who are cult members to the appropriate authorities, but also by embarking on mass action and campaign against cultists. Such a measure has to some extent been successfully applied in the past to handle certain campus unrests due to cult activities (Orewa, 1997; Echekwube, 1999, Smah, 2003).

The foregoing notwithstanding, some people are of the view that the problem of campus cultism eradication should mainly be the responsibility of the institutions' authorities (Aboribo, 1999; Alemika, 2000; Akinkugbe, 2001; Abbah \& Ogunmakin, 2002). What the institutions must do in this regard should not end with a mere compilation of normative dos and don'ts. They must not shy away from admitting that there is a continued presence of dangerous and criminal groups in these institutions as though the authorities were benefiting from their presence and activities. The authorities should, on the contrary, undertake the pictorial identification, display and publication of all identified student cultists as a way of checking their influence on other students on campus. Besides, institutions' authorities should not only expel and hand over identified student cultists to the police, but must also ensure that such cultists are not re-admitted into the same or other Universities. Moreover, institutions' authorities should ensure the establishment and/or strengthening of University Security Committees (USC) and Security Division and equipping them with necessary skills and paraphernalia to make them capable of handling internal security problems without recourse to the Nigeria Police.

On the other hand, according to Maduike (1994), the roots of the secret cult saga are traceable to the homes. He believes that many homes have failed their children because parents have little or no time for their children's moral training. Moreover, some parents' lack of moral rectitude and membership of secret cults are not helping matters either. Therefore the way forward is for parents to provide the much needed moral training and love for their children, as well as ensure that regular social contacts between them and their children and wards also exist. As stated by Olukoya (1994), in our efforts to eradicate cultism in tertiary institutions of learning, we should go back to the basics of life: namely, adequate parental care which includes strict discipline at the formative and impressionable years of the child. For a child to grow up properly and to prevent him from developing the tendency to become a future criminal, parents need to make provision for interaction through talking; listening; cross-fertilizing ideas; and sharing activities, laughter, sorrow, joy, leadership roles and responsibilities and so on.

Finally, here, since the menace of cultism traverses the institutions of higher learning and the larger society alike, it is natural to expect that its eradication would necessarily require the conscious intervention of the Governments (Federal and State). It is in the light of this that Orewa (1997) suggests that Government should 
return secondary schools to their missionary proprietors as a way of nipping cultism in the bud. According to him, Government take-over of schools in 1975/76 is paying its toll on us because most of the members of the numerous campus cults are the products of the 'godless' education which is sequel to the State take-over of schools.

Moreover, the Federal Government through its Ministry of Justice should lucidly and unequivocally define and classify all behaviours that have any hue of cultism (in the campus or larger society) in the form of a bill and send same to the National Assembly for passage into law specifying the concomitant penalties for culprits. In addition, the various Governments should make the academic environment of the tertiary institutions conducive for the pursuit of academic excellence. This will of course make the filthy activities of cult members unattractive to nonmembers, especially the freshmen who are usually targets for recruitment at the beginning of new academic years.

Now that the reasons why students join secret cults on campuses in Nigeria, as well as the harmful effects of secret cults and strategies for eradicating the incidence have been presented more or less in the realm of conjecture, there is need to use empiricism to determine what the situation really is at the present time regarding these variables. Hence the study reported in the next section of this paper.

\section{METHODOLOGY}

The study was a survey in design. It was a descriptive survey as questionnaire was used in data collection. It covered all the state-owned higher educational institutions in Delta State of Nigeria. These are Delta State University Abraka; Colleges of Education, Agbor, Warri and Mosogar; and the Delta State Polytechnics, Oghara, Ogwashi-Uku and Ozoro. A total of 1,000 students, lecturers and school administrators (that is, 665 students, 220 lecturers and 115 school administrators) were systematically randomly selected to complete the questionnaire on the reason why students join secret cults on the campuses, as well as on the harmful effects of the incidence of secret cults, and strategies for eradicating it.

Three research questionnaires were formulated to guide study, as follows:

1. What are the opinions of students, lecturers and school administrators regarding the reasons why students join secret cults in higher educational institutions?

2. What are the opinions of students, lecturers and school administrators with respect to the effects of secret cults in the higher educational institutions?

3. What are the opinions of students, lecturers and school administrators regarding strategies for eradicating secret cults from the higher educational institutions?

The 31-item questionnaire used to collect data in the study was of the Likert scale type with four points (Strongly Agree, Agree, Disagree and Strongly Disagree), scored 4-1. The questionnaire was validated at a higher educational institution outside the sample for the study through the test-retest method; and the reliability coefficient was $r=0.83$. Then Multiple Classification Analysis (MCA) was employed to determine the construct validity of the instrument; and its value was 0.87 .

Percentages were used to analyse the data in a way to establish the strength of the views of stakeholders regarding the reasons why students join secret cults in the higher educational institutions, as well as the effects of the incidence and strategies for eradicating it from the institutions.

\section{RESULTS AND DISCUSSION}

This study had set out to establish in part the possible reasons why the students in higher educational institutions in Delta State of Nigeria (the State being used as a mirror of the country) join secret cults on campuses. In this regard, the results are that all stakeholders (namely, students, lecturers, and school administrators) agree that students join secret cults on campuses

(1) for protection against oppressive students and the perceived aggression and hostility of wicked lecturers $(88.9 \%)$; and

(2) to terrorize lecturers to pass their courses at all cost (66.7\%) (Table1).

These results are supported in the literature by Musa (1998) and Egbule (2006) who had informed that students join secret cults on campuses to terrorize lecturers to pass their courses at all cost, as well as for provision of security services to new initiates, and generally shielding them from oppressive students and the perceived aggression and hostility of wicked 
lecturers. However, the suggestion by Musa (1998) and Egbule (2006) that students, in addition, join secret cults in order to engage in drug-peddling on campuses is not supported by the stakeholders $(22.2 \%)$, neither are the claims that students generally join secret cults to carry out terrorist activities and that if female students, in order to assist the male groups as spies, and generally meeting their sexual needs supported (as only $22.2 \%$ and $0 \%$ respectively endorsed these reasons).

The second part of the research dealt with possible effects of secret cults in the institutions. The effects highlighted by stakeholders all except one reinforce the views and research reports earlier presented in the literature (Table $2)$. The only view not supported is that cultists are prone to contracting HIV and spreading same because they frequently engage in sex orgies (as only $22.2 \%$ of the sample endorsed it). Thus, the confirmed effects of secret cults in the institutions are as follows:

- cultism being an evil association which puts a bondage on its members and denies them of personal liberty $(100 \%)$;

- cult activities leaving members with little time for serious academic work, leading to reduction in genuine academic work (100\%);

- cult activities leading to certificates not being backed up with hard work and true academic struggle, leading to reduction in manpower quality (100\%);

- cultism leading to maiming and killing of rival cult members, as well as innocent students $(100 \%)$;

- identified and expelled cultists possibly becoming school drop-outs, robbers, prostitutes, drug-peddlers and maladjusted people in life $(88.9 \%)$;

- cultists being haunted throughout their educational pursuit by fear of being apprehended and treated as criminals (100\%);

- cultists being at the mercy of the directives of their cult groups: to steal/rob violently; to tell lies to raise money for the cult groups; or if female members, to be "call girls" to bring money to their cult boy-friends $(88.9 \%)$;

- by design, cultists seriously abusing hard drugs - indian hemp, cocaine, heroin and alcohol - and in that state of mind, committing heinous crimes $(77.8 \%)$;

- cultists constantly living in fear of attacks from rival cult groups $(100 \%)$; 


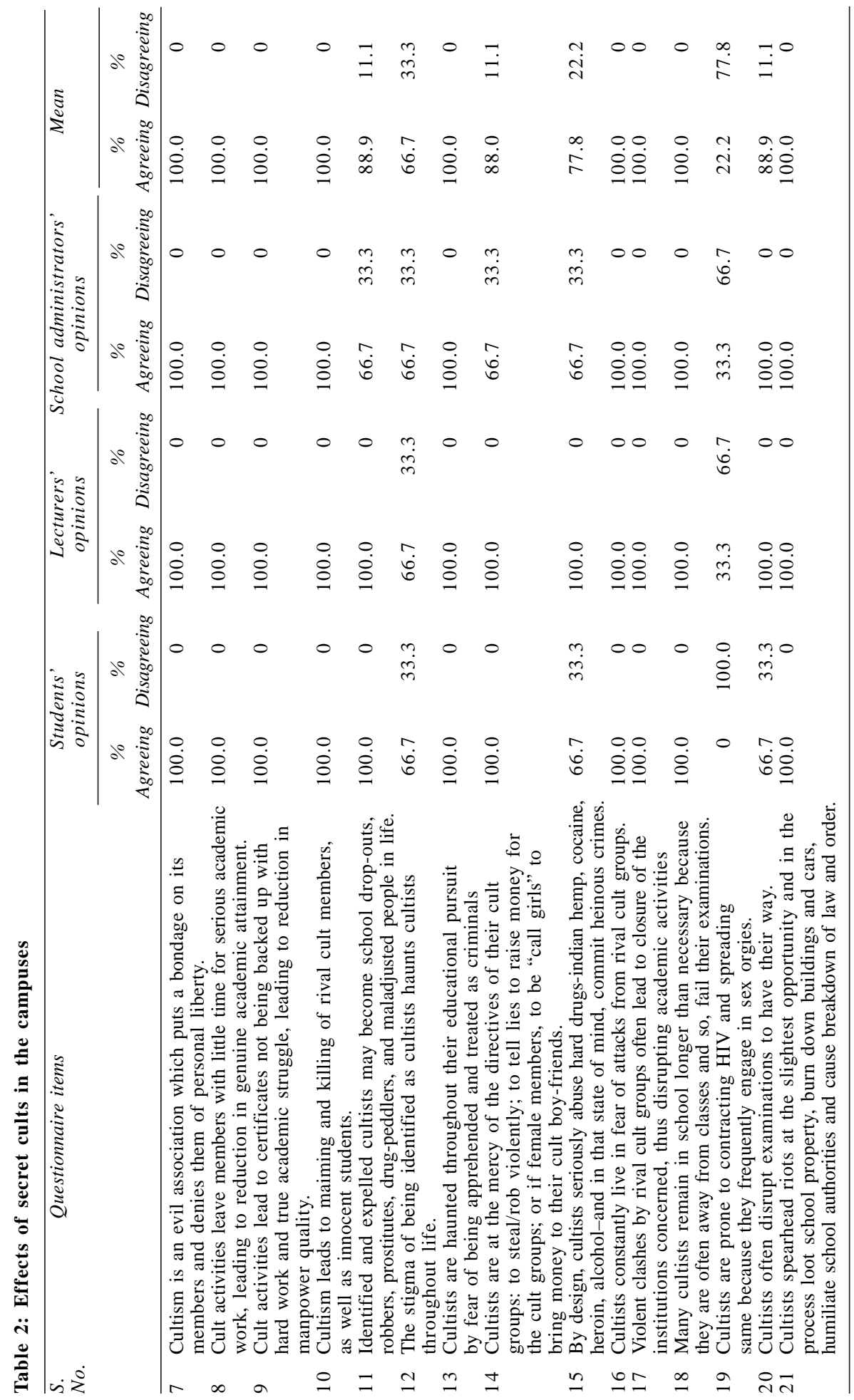


- violent clashes by rival cult groups often leading to closure of the institutions concerned, thus disrupting academic activities (100\%);

- many cultists remaining in school longer than necessary because of their often being away from classes and so, failing their examinations $(100 \%)$;

- cultists often disrupting examinations to have their way $(88.9 \%)$; and

- cultists spearheading riots at the slightest opportunity and in the process looting school property, burning down buildings and cars, humiliating school authorities and causing breakdown of law and order (100\%). All these results had been highlighted in the reviewed literature by Ogbu (2001), Onodarho (1999), Egbule (2006); Igborgbor (2006), Egbule (2006); Onodarho (1999), Egbule (2006); Otoibhi (1999), Igborgbor (2006); and Igborgbor (2006).

The third part of the research being reported here dealt with ascertaining possible strategies for effectively eradicating secret cults from the higher educational institutions. The stakeholders are agreed to varying degrees on the following strategies: (Table 3):

- any effective strategies for eradicating secret cults from the institutions having to involve students, the institutions' authorities, parents and government (100\%);

- non-cult students being assured of personal safety as they are encouraged by school authorities to give information on their secret cult fellow students $(77.8 \%)$;

- the institutions undertaking the pictorial identification, display and publication of all identified student cultists $(77.8 \%)$;

- secret cult members once identified and expelled not being readmitted into the same or other institutions (88.9\%);

- all identified and expelled secret cult members being handed over to the police for prosecution $(77.8 \%)$;

- parents themselves having to shun membership of secret cults, showing their children love and providing social contacts between them and their children (100\%); and

- the National Assembly having to pass into law a bill sent to it by the Ministry of Justice which clearly spells out all behaviours that have any hue of cultism, as well as specifies the concomitant penalties for culprits $(77.8 \%)$.

Again, though to varying degrees, all the results of the research in the area of strategies that could effectively eradicate secret cults from the institutions, reinforce the strategies earlier identified in the literature, in the following order: Smah (2000), Awe (2001), Adeola (1997); Orewa (1997), Echekwube (1999), Smah (2003); Aboribo (1999), Alemika (2000), Akinkugbe (2001), Abbah \& Ogunmakin (2002); Maduike (1994); and Olukoya (1994).

\section{CONCLUSION}

The conclusion reached after examining the results of the study is that the menace of secret cults in higher educational institutions in Delta State of Nigeria, as elsewhere in Nigeria, is real, that it is an ill-wind that does not blow any stakeholders in the educational system any good, and that to eradicate it from the higher educational institutions, all stakeholders must be involved in providing a broad-based solution.

\section{RECOMMENDATIONS}

Based on the results of the study, the following recommendations are made:

1. to counter the false information being peddled by cult chieftains and their agents, group counselling sessions and seminars should periodically be undertaken by the institutions' authorities to assure students, especially the new intake at the beginning of the school year, that once they abide by the rules and regulations of the institutions, they have nothing to fear, that the Authorities and lecturers are there to provide their needs, and once they attend lectures punctually and regularly, read their books and do their assignments, they do not need godfathers to terrorize lecturers to enable them pass their examinations;

2. innocent students being terrorized by cult members to join their cult groups should report such cultists to the counsellors and Dean of Students in order to free themselves from the shackles of such cultists in a most discreet manner;

3. anti-cult clubs should be formed in the institutions which through their various activities should expose the evils of cultism in all its ramifications; and

4. all extant laws regarding secret cults in the institutions should be religiously enforced to act as a deterrent to students wanting to join the secret cults. 


\section{ACKNOWLEDGEMENT}

The authors are grateful to the students, lecturers and school administrators of the Delta State University, Abraka, Nigeria, and the Delta State-owned Colleges of Education, Agbor, Warri and Mosogar, and the Polytechnics, Oghara, Ogwashi-Uku and Ozoro who readily completed the questionnaire used to collect data in the study.

\section{NOTES}

In local University parlance in Nigeria, the term JAMBITES refers to new entrants to the University system who come in through the Joint Matriculation Examination (JME) conducted by the Joint Admissions and Matriculation Board (JAMB) in the country. It is often used derogatorily to mean new and inexperienced students in the University.

\section{REFERENCES}

Abbah, T. and O.Ogunmakin. 2002. "Poly Ibadan Tightens Security to Curb Cultism." The Punch, February 11, 2002, p. 12.

Aboribo, R.I. 1999. "Secret Cults in Nigerian Universities: Politico-economic and Spiritual Dimensions." Knowledge Review, 1(1): 31-38.

Adeola, I.D.A. 1997. "Secret Cults in Nigerian Higher Institutions of Learning: A Periscopal Appraisal," (pp. 51-69) in A.O. Ogunbameru (ed.), Readings on Campus Secret Cults. Ile-Ife: Kintel Publishing House.

Akinkugbe, O.O. 2001. "The Piper, the Tune and University Autonomy." The Nigerian Society Scientist, 4(1): 2-6.

Alemika, E.E.O. 2000. "Management of Student Unions and Anti-cult Mobilization in Nigerian Tertiary Educational Institutions," Paper presented at the Workshop on Security Issues in the Eradication of Cultism in Tertiary Institutions. Held at the Auditorium of the National Universities Commission, Federal Capital Territory, Abuja, May 25 and 26, 2000.

Awe, O.O. 1999. "The Role of Parents and Religious Groups in Combating Cult Menace and Campus Brigandage," (pp. 1-9) in T. Ogunye (ed.), Citadels of Violence. Lagos: Committee for the Defence of Human Rights.
Echekwube, A.O. 1999. "Cultism in Our Higher Institutions: the Scourge of a Nation." Knowledge Review, 1(1): 24-30.

Egbule, J.F. 2006. "Conceptualization of Cultism in Secondary Schools," Paper read at a Workshop on Cultism for Principals of Secondary Schools in Delta State of Nigeria, Organized by the State PostPrimary Education Board, Asaba, Nigeria, November 1 and 2, 2006.

Igborgbor, F.O. 2006. "Cultism and its Impact on the Learning Process." Paper read at a Workshop on Cultism for Principals of Secondary Schools in Delta State of Nigeria, Organized by the State PostPrimary Education Board, Asaba, Nigeria, November 1 and 2, 2006.

Maduike, C. 1994. "Secret Cults: A Possible Solution." The Daily Champion, April 12, 1994, p. 5.

Musa, N. 1998. "The Emergence of Secret Cults in Tertiary Institutions in Nigeria and their Effects on Learning and Discipline," (pp. 51-59) in P.O. Itedjere (ed.), Current Issues in Nigeria Educational System, Benin City, Nigeria: Osasu Publishers.

Ogbu, U.K. 2001. The Scourge of the Vandals: Nature and Control of Cults in Nigerian University System, Enugu: Joen Printing and Publishing Company.

Ogharaerumi, B.S.U. 2006. "Evolving strategies to Curb Cultism." Paper read at a Workshop on Cultism for Principals of Secondary Schools in Delta State of Nigeria, Organized by the State Post-Primary Education Board, Asaba, Nigeria, November 1 and 2, 2006.

Olukoya, S. 1994. "Cult War: Secret Cults Make Life Insecure on Campus." Newswatch News Magazine, 19(13), March 28, 1994, pp. 9 and 10.

Onodarho, A. 1999. ANCHOR: Secret Cult Activities on Campus Exposed: Warning Guide for Students of Tertiary Institutions (Revised Edition), Enugu: SNAP Press Ltd.

Orewa, G.O. 1997. We Are All Guilty in the Nigerian Crisis. Ibadan: Spectrum Books Ltd.

Otoibhi, B. 1999. Campus Cults: Help for Cultists. Lagos: Temple Re-builder Ministry.

Smah, S.O. 2000. "Social Deviance on A Nigeria University Campus: the University of Jos, Nigeria", (pp. 123-143) in Y. Lebeau and M. Ogunsanya (eds.), The Dilemma of Post-colonial Universities, Ibadan: IFRA and ABB.

Smah, S.O. 2003. "Campus Cultism and Violence: Implications for University Management," Nigerian Sociological Review, 1(2): 17-25. 